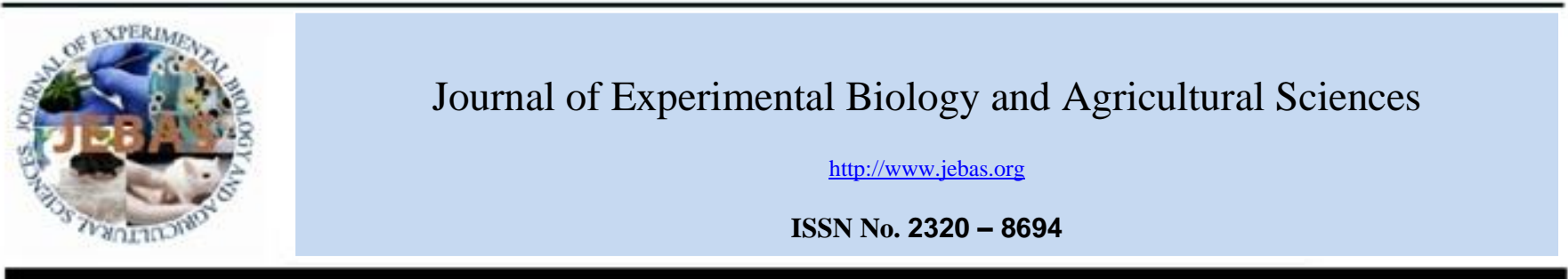

\title{
PRELIMINARY STUDIES ON ISOLATION AND SCREENING OF ANTIBIOTIC PRODUCING SYMBIOTIC BACTERIA FROM STARFISH (Protoreaster nodosus) COLLECTED FROM COASTAL AREA TAKALAR REGENCY, INDONESIA
}

\author{
Muhammad Danial Fajri ${ }^{1}$, Subehan Lallo ${ }^{2}$, Sartini Sartini ${ }^{3 *}$
}

${ }^{1}$ Magister Program, Faculty of Pharmacy Hasanuddin University, Makassar 90245, Indonesia

${ }^{2}$ Departement of Phytochemistry, Faculty of Pharmacy Hasanuddin University, Makassar 90245, Indonesia

${ }^{3}$ Departement of Microbiology, Faculty of Pharmacy Hasanuddin University, Makassar 90245, Indonesia

Received - March 16, 2021; Revision - April 10, 2021; Accepted - April 17, 2021

Available Online - April 25, 2021

DOI: http://dx.doi.org/10.18006/2021.9(2).183.188

\section{KEYWORDS \\ Protoreaster nodosus \\ Symbiotic bacteria \\ Antibacterial activity \\ Disc diffusion assay}

\begin{abstract}
Marine organisms are well known for the availability of bioactive compounds which have various biological activities including antibacterial activity. Likewise, their symbiotic bacteria can also produce compounds that have similar activities. The purpose of this study was to isolate and screen the symbiotic bacteria from starfish (Protoreaster nodosus) collected from coastal area Takalar Regency, South Sulawesi, Indonesia. Isolation was carried out by the pour plate method using nutrient agar medium dissolved in sterile seawater. The isolated symbiotic bacteria were purified by using the quadrant method. The pure isolate was culture through submerged fermentation using nutrient broth media enriched with $1 \%$ yeast extract and sterile seawater for 7 days. The selected symbiont bacterial isolates were tested for their antibacterial activity against gram-positive and gram-negative bacteria using disc diffusion assays. The results of fermentation were separated from the biomasses and tested for antibacterial activity against Staphylococcus aureus (S. aureus, ATCC 25923), Bacillus subtilis (B. subtilis, ATCC 6633), Salmonella typhi (S. typhi, NCTC 786), and Escherichia coli (E. coli, ATCC 25923). The results of study revealed that four symbiotic bacteria (SB 1T, SB 2T, SB 3T, and SB 4T) were successfully isolated. All the SB isolates have good antibacterial activity against all tested bacterial strains with an average diameter of inhibition zone larger than $11 \mathrm{~mm}$. Among all isolates, isolate SB 4T showed a remarkable size of zones growth inhibition $(>15 \mathrm{~mm})$ against all tested bacterial strains. Thus, the symbiotic bacteria isolated from $P$. nodosus in this study have a promising broad-spectrum antibacterial activity.
\end{abstract}

* Corresponding author

E-mail: sardj@farmasi.unhas.ac.id (Sartini)

Peer review under responsibility of Journal of Experimental Biology and Agricultural Sciences.

Production and Hosting by Horizon Publisher India [HPI] (http://www.horizonpublisherindia.in/).

All rights reserved.
All the articles published by Journal of Experimental Biology and Agricultural Sciences are licensed under a Creative Commons Attribution-NonCommercial 4.0 International License Based on a work at www.jebas.org.

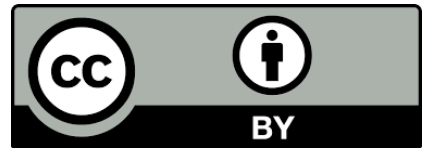




\section{Introduction}

Various marine organisms, including algae, sponges, and starfish have various bioactive compounds that can be used to produce medicinal natural products (Habbu et al., 2016; Blunt et al., 2018). Some starfish species such as Certonardoa semiregularis, Stellaster equestris, Astropecten indicus, Protoreaster linckii, and $P$. nonudus are well known for their antimicrobial activity (Chamundeeswari et al., 2012; Prabhu \& Bragadeeswaran, 2013; Mohammed Husain, 2019). Several secondary metabolites such as steroids, steroidal glycosides, anthraquinones, alkaloids, phospholipids, peptides, and fatty acids were found in starfish. Among these, bioactive compounds such as polyhydroxylated sterols and their derivatives possess antibacterial activity agains several strains of pathogen bacteria (Dong et al., 2011; Thao et al., 2015; Cockroft et al., 2019; Ivanchina et al., 2019).

Previous studies have shown that various symbiotic microorganisms were associated with marine invertebrates and produced secondary metabolites with antimicrobial properties (Kamke et al., 2010; Thomas et al., 2010; Sartini et al., 2014; Ismail et al., 2016). These microorganisms include bacteria, actinomycetes, and fungi. Santhi et al. (2017) reported the presence of symbiotic Bacillus sp. with the sponge. Similarly, Nakagawa et al. (2017) reported the presence of symbiotic bacteria in coelomic fluid isolated from two species of starfish i.e., Patiria pectinifera and Asterias amurensis which were identified as Helicobacterrelated taxon (Nakagawa et al., 2017). However, to the best of our knowledge, no studies have been carried out on the isolation and screening of antibacterial-producing symbiotic bacteria from starfish particularly $P$. nodosus species.

Moreover, the differences in the environment where the starfish live can also affect the microbial symbiont strain found in the starfish. Similarly, Jackson et al. (2018) reported that anatomical regions of sea star, microbial community, and the difference in geographical location affect the sea star microbiome and in particular may reduce the bacterial cells (by 2-log reduction) in the coelomic fluid of sea stars. The combination of environmental factors such as temperature, salinity, and $\mathrm{pH}$ are believed to be the driving factors that affect the microbial community associated with sea stars (Jackson et al., 2018).

Therefore, the current study was carried out to investigate the symbiotic bacteria isolated from the starfish ( $P$. nodosus) collected from coastal area Takalar Regency, South Sulawesi, Indonesia. Further, the screening of antibacterial activity of the isolated symbiotic bacteria against several gram-positive and gramnegative bacteria was also performed.

\section{Materials and Methods}

\subsection{Materials}

Starfish (P. nodosus) was collected from the coastal area Takalar Regency, South Sulawesi, Indonesia (Figure 1). Nutrient agar, nutrient broth, yeast extract, and Muller Hinton agar were purchased from Merck (Germany). Seawater (collected from the coastal area Takalar Regency, South Sulawesi, Indonesia) were sterilized using an autoclave. Bacterial test strain Staphylococcus aureus (S. aureus, ATCC 25923), Bacillus subtilis (B. subtilis, ATCC 6633), Salmonella typhi (S. typhi, NCTC 786), and Escherichia coli (E. coli, ATCC 25923) were obtained from the culture collection of Bacteriology Unit at Department of Microbiology, Faculty of Pharmacy Hasanuddin University, Indonesia. All other reagents and solvents used in this study were of the analytical grade.

\subsection{Isolation of symbiotic bacteria}

In the current study, for the isolation of symbiotic bacteria, the pour plate method was used. Briefly, samples of starfish ( $P$. nodosus) were cut into pieces and weighed $25 \mathrm{~g}$, this amount was then crushed with a blender and $250 \mathrm{~mL}$ volume was prepared by adding sterile seawater. This was followed by the serial dilution of the mixture up to $10^{-5}$ dilution factor. From each dilution, $100 \mu \mathrm{l}$ was taken out by a micropipette and mixed into nutrient agar media which has been prepared in a petri dish by pour plate method. Furthermore, the culture was incubated for 24-48 hours at $37^{\circ} \mathrm{C}$. The purification of symbiotic bacteria isolates was performed through the quadrant method until pure isolates were obtained.

\subsection{Screening of antibacterial chemical producing symbiotic bacteria}

\subsubsection{Production of bioactive compounds through submerged fermentation}

Each pure symbiotic bacterial isolate was inoculated into the sterile nutrient broth and incubated for 24 hours at $37^{\circ} \mathrm{C}$. Culture starter $(10 \% \mathrm{v} / \mathrm{v})$ was poured into Erlenmeyer flask containing nutrient broth enriched with $1 \%$ yeast extract, followed by incubation for 7 days at $37^{\circ} \mathrm{C}$ under constant shaking (200 rpm). After 7 days of incubation, the fermented liquid (supernatant) was separated from the biomasses (sediment). This was followed by the extraction (3 times) of this fermented liquid with ethyl acetate solvent $(1: 1 \mathrm{v} / \mathrm{v})$ in a separating funnel for 90 minutes. The extract was obtained by solvent evaporation and then stored in a desiccator for further use. 


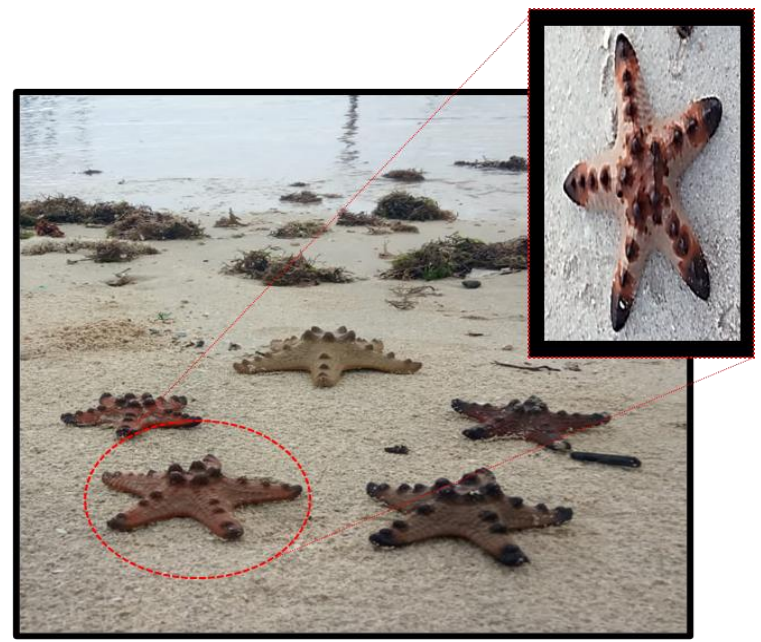

Figure 1 Starfish (P. nodosus) collected from coastal area Takalar Regency, South Sulawesi, Indonesia
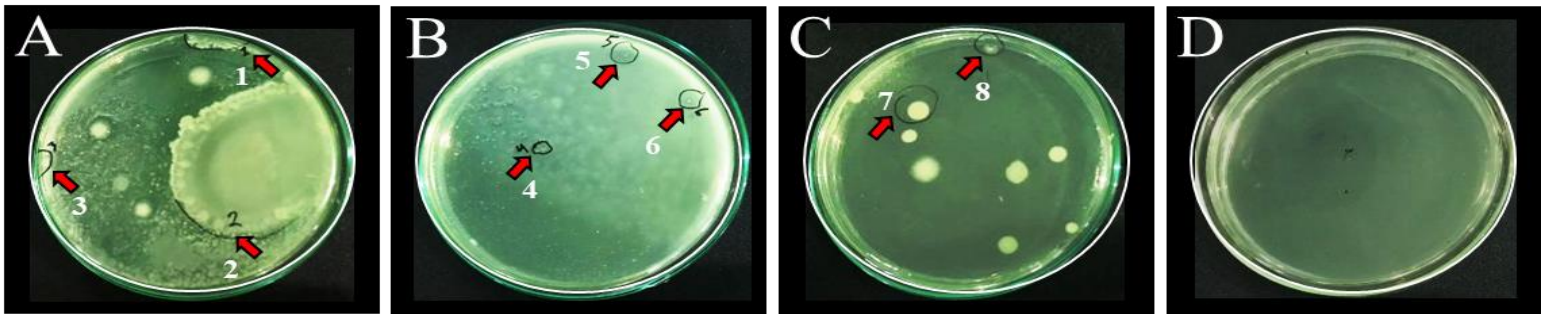

Figure 2 The growth of symbiotic bacteria isolated from starfish (Protoreaster nodosus) on nutrient agar media dissolved in sterile seawater after 2 days incubation at $37^{\circ} \mathrm{C}$
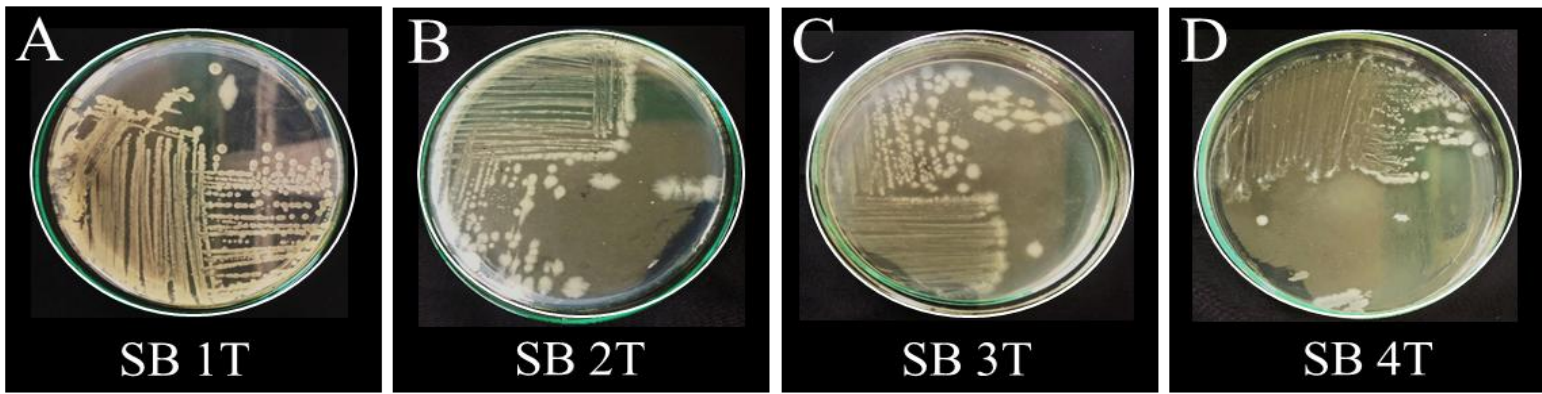

Figure 3 Four selected symbiotic bacteria isolates from starfish (Protoreaster nodosus) in nutrient agar media
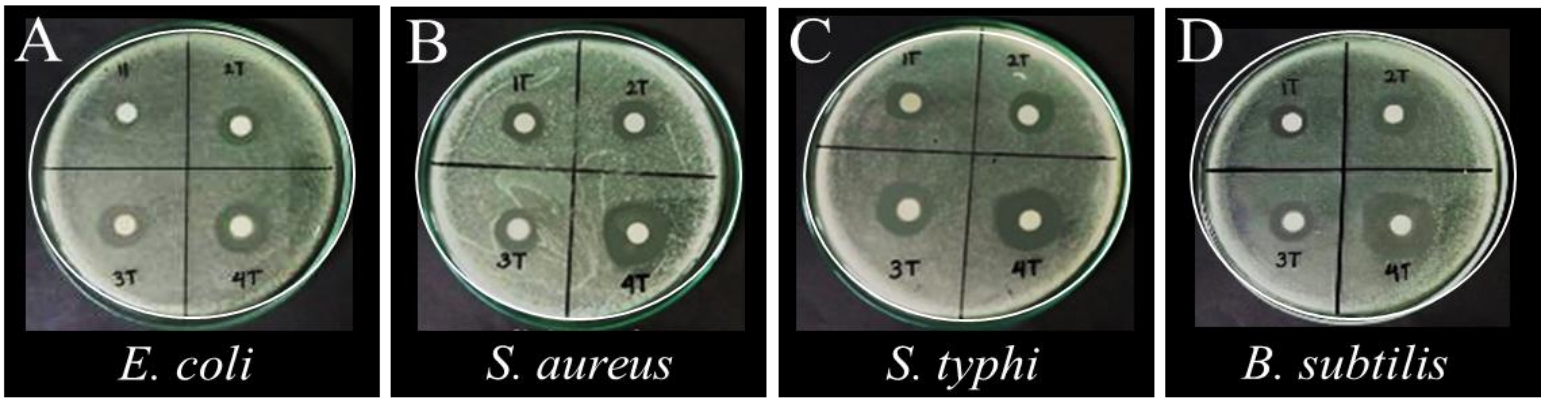

Figure 4 Antibacterial activity of symbiotic bacteria isolates after fermentation using disc diffusion assay

Journal of Experimental Biology and Agricultural Sciences http://www.jebas.org 
Table 1 Characteristic of the symbiotic bacteria isolates

\begin{tabular}{|ccccc|}
\hline Isolates & Colony shape & Edge of colony & Elevation & Colour \\
\hline SB 1T & Irregular & Undulate & Convex & White \\
\hline SB 2T & Irregular & Undulate & Raised (height is visible, but flat over & White \\
& Round & Flat & Convex & White \\
\hline BS 3T & Irregular & Flat & Convex & White \\
\hline BS 4T & & & &
\end{tabular}

Table 2 Diameter of inhibition zone of symbiotic bacteria isolates after fermentation 2 days using disc diffusion assay

\begin{tabular}{|c|c|c|c|c|}
\hline \multirow{2}{*}{ Isolates } & \multicolumn{4}{|c|}{ Diameter of inhibition zone $(\mathrm{mm} \pm \mathrm{SD})$} \\
\hline & E. coli & S. aureus & S. typhosa & B. subtilis \\
\hline SB 1T & $11.13 \pm 0.02$ & $11.72 \pm 0.30$ & $11.70 \pm 0.08$ & $11.28 \pm 0.01$ \\
\hline SB 2T & $11.78 \pm 0.04$ & $11.78 \pm 0.12$ & $11.16 \pm 0.05$ & $11.28 \pm 0.06$ \\
\hline BS 3T & $12.71 \pm 0.20$ & $11.27 \pm 0.01$ & $12.13 \pm 0.03$ & $12.08 \pm 0.01$ \\
\hline BS 4T & $15.52 \pm 0.28$ & $17.36 \pm 0.36$ & $18.46 \pm 0.38$ & $18.53 \pm 0.23$ \\
\hline
\end{tabular}

Values are expressed as mean averages \pm SD of three different batches of symbiotic bacteria

\subsubsection{In vitro antibacterial assay using a disc diffusion assay}

Antibacterial activity was evaluated using disc diffusion assay as described by Sartini et al. (2014) with slight modification. Briefly, $20 \mu \mathrm{L}$ supernatant was pipetted on the paper disc (6-mm diameter). Each disc was then placed on to Muller Hinton agar ( $\mathrm{pH} 7.0 \pm 0.2)$ containing $1 \mathrm{~mL}$ of $10^{8}$ cell $/ \mathrm{ml}$ bacterial suspensions ( $S$. aureus ATCC 25923, B. subtilis ATCC 6633, S. typhiNCTC 786, and $E$

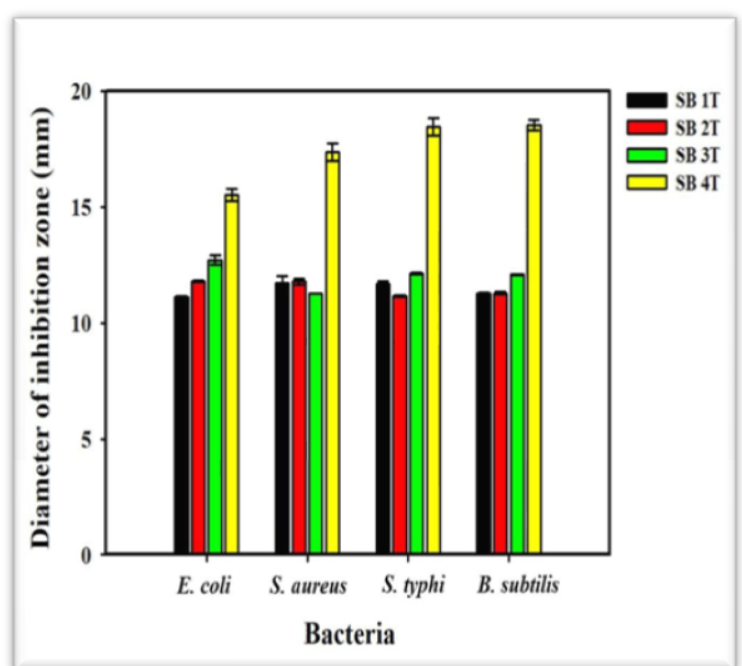

Figure 5 Diameter of inhibition zone of symbiotic bacteria isolates against E. coli, S. aureus, S. typhi, and B. subtilis coli ATCC 25923), this was followed by the 24 hours incubation at $37^{\circ} \mathrm{C}$. The result of antibacterial activity is expressed as the diameter of the inhibition zone (DIZ).

\section{Results and Discussion}

\subsection{Isolation of symbiotic bacteria}

The isolation of symbiotic bacteria from the starfish ( $P$. nodosus) collected from coastal area Takalar Regency, South Sulawesi, Indonesia was carried out by using the pour plate method in nutrient broth media through $10^{-1}$ to $10^{-5}$ dilutions. After 2 days of incubation, the growths of bacteria in various dilutions $\left(10^{-1}\right.$ to $10^{-}$ ${ }^{5}$ ) were macroscopically observed. Based on the macroscopic differences in the shape of the colonies, the purification was performed using the quadrant method. The shape of bacterial colonies was shown in Figure 2. The results of this study revealed that 8 colonies can be continued for purification. These results confirmed the presence of microorganisms associated with starfish ( $P$. nodosus $)$ and the symbiotic bacteria were successfully isolated from the host. These results establishing the data related to the symbiotic bacteria that were isolated from starfish collected from coastal area Takalar Regency, South Sulawesi, Indonesia. Although various previous studies have been already reported the presence of several symbiotic bacteria from starfish species but this is the first study that evaluated the effect of the environment and geographical location of the Takalar Regency, South Sulawesi,

Journal of Experimental Biology and Agricultural Sciences http://www.jebas.org 
Indonesia on the occurrence of the symbiotic microorganism associated with starfish. As reported by Jackson et al. (2018), the combination of environmental (temperature, salinity, and $\mathrm{pH}$ ) and host factors (mucosal layers, diet, exposure to coelomocytes, and secondary metabolites) affect the occurrence and variety of symbiotic bacteria of starfish (Jackson et al., 2018).

Further, figure 3 showed that the selected symbiotic bacterial isolates were free from the contamination after inoculation in nutrient agar media. These isolates namely SB 1T, SB 2T, SB 3T, and SB 4T have different shapes, edge of colonies, elevation, and colour (Table 1).

The shape of the colony varied from irregular shape to round shape. The edge of the colony was undulate and flat/even. The elevation of the colony was recognized as convex or raised and the colour of the isolate was observed to have a white colour. These 4 isolates were then further fermented to produce secondary metabolites that possess antibacterial activity.

\subsection{Screening of antibacterial-producing symbiotic bacteria}

Previous studies have been reported the isolation of symbiotic microbes from marine biota, especially from sponges, macroalga, and holothurian. These symbiotic microbes are well known to produce secondary metabolites that possess several biological activities including antimicrobial activity (Ismail et al., 2016; Kuo et al., 2019; Pringgenies et al., 2019). However, information's regarding the symbiotic bacteria from starfish that possess antibacterial activities are still lacking.

In the current study, four isolated isolates viz., SB 1T, SB 2T, SB $3 \mathrm{~T}$, and SB $4 \mathrm{~T}$ were selected for evaluating their antibacterial potential against the selected gram-positive ( $S$. aureus ATCC 25923 and B. subtilis ATCC 6633) and gram-negative (E. coli ATCC 25923 and S. typhiNCTC 786) bacteria by using zone of inhibition assays. These results are incorporated in table 2 and figure $4 \& 5$. The results of the study revealed that the average DIZ of SB 1T, SB 2T, SB 3T, and SB 4T against the tested bacterial strains are $11.45 \mathrm{~mm}, 11.49 \mathrm{~mm}, 12.05$, and 17.47, respectively. All the SB isolates have good antibacterial activity against all tested bacterial strains and among these, isolate SB 4T showed a remarkable size of zones growth inhibition (> $15 \mathrm{~mm}$ ). Thus, the symbiotic bacteria isolated from $P$. nodosus in this study have a promising broad-spectrum antibacterial activity for therapeutic purposes.

\section{Conclusion}

Four symbiotic bacteria i.e., SB 1T, SB 2T, SB 3T, and SB 4T were successfully isolated from the starfish collected from coastal area Takalar Regency, South Sulawesi, Indonesia. All the SB isolates have good antibacterial activity against the broad spectrum gram-positive and gram-negative bacterial strains and in particular, the isolate SB 4T showed a remarkable size of zones growth inhibition. However, in this study molecular identification of these isolates has not yet been conducted. Future studies are required for the characterization of these isolates through molecular identification.

\section{Acknowledgements}

This research was supported by a grant from the Ministry of Research, Technology \& Higher Education and Hasanuddin University, Republic of Indonesia (Hibah Magister Grant no. 1517/UN4.22/PT.01.03/2020).

\section{Conflict of Interest}

Authors declare that they have no conflict of interest.

\section{References}

Blunt JW, Carroll AR, Copp BR, Davis RA, Keyzers RA, Prinsep MR (2018) Marine natural products. Natural Product Report 35: 853.

Chamundeeswari K, Saranya S, Rajagopal S (2012) Exploration of potential antimicrobial activity of sea star astropecten indicus. Journal of Applied Pharmaceutical Science 2: 125.

Cockroft NT, Cheng X, Fuchs JR (2019) STarFish: A stacked ensemble target fishing approach and its application to natural products. Journal of Chemical Information and Modeling 59: 4906-4920.

Dong G, Xu T, Yang B, Lin X, Zhou X, Yang X, Liu Y (2011) Chemical constituents and bioactivities of starfish. Chemistry and Biodiversity $8(5)$ : 740-791. https://doi.org/10.1002/cbdv.200900344.

Habbu P, Warad V, Shastri R, Madagundi S, Kulkarni VH (2016) Antimicrobial metabolites from marine microorganisms. Chinese Journal of Natural Medicines 14: 101-116. DOI: 10.1016/S18755364(16)60003-1.

Ismail A, Ktari L, Ahmed M, Bolhuis H, Boudabbous A, Stal LJ, Cretoiu MS, El Bour M (2016) Antimicrobial activities of bacteria associated with the brown alga Padina pavonica. Frontiers in Microbiology 7: 1072. DOI: 10.3389/fmicb.2016.01072.

Ivanchina NV, Kicha AA, Malyarenko TV, Ermolaeva SD, Yurchenko EA, Pislyagin EA, Van Minh C, Dmitrenok PS (2019) Granulatosides D, E and other polar steroid compounds from the starfish Choriaster granulatus. Their immunomodulatory activity and cytotoxicity. Natural Product Research 33(18):2623-2630. doi: 10.1080/14786419.2018.1463223. 
Jackson EW, Pepe-Ranney C, Debenport SJ, Buckley DH, Hewson I (2018) The microbial landscape of sea stars and the anatomical and interspecies variability of their microbiome. Frontiers in Microbiology 9: 1829. doi: 10.3389/fmicb.2018.01829.

Kamke J, Taylor MW, Schmitt S (2010) Activity profiles for marine sponge-associated bacteria obtained by $16 \mathrm{~S}$ rRNA vs $16 \mathrm{~S}$ rRNA gene comparisons. The ISME Journal 4(4) 498-508.

Kuo J, Yang YT, Lu MC, Wong TY, Sung PJ, Huang YS (2019) Antimicrobial activity and diversity of bacteria associated with Taiwanese marine sponge Theonella swinhoei. Annals of Microbiology 69(3):1-13.

Mohammed Husain SBO, Chamundeeswari K, Chitra M (2019) Antibacterial potential of sea star Protoreaster linckii from Mandapam, southeast coast of India. Research Journal of Life Sciences, Bioinformatics, Pharmaceutical and Chemichal Sciences 5: 62-72.

Nakagawa S, Saito H, Tame A, Hirai M, Yamaguchi H, Sunata T, Aida M, Muto H, Sawayama S, Takaki Y (2017) Microbiota in the coelomic fluid of two common coastal starfish species and characterization of an abundant Helicobacter-related taxon. Scientific Reports 7: 1-10.

Prabhu K, Bragadeeswaran S (2013) Antibacterial activity of starfish Stellaster equestris from Southeast Coast of India. Journal of Coastal Life Medicine 1(3): 210-216.

Pringgenies D, Yudiati E, Djunaedi A, Widi Santosa G, Koesoemadji (2019) Explorations of symbiotic microbe from sea Cucumber gut as an anti-multi-drug resistant microbe agent for utilization in hand. AACL Bioflux 12(3): 737-747.

Santhi LS, Prasad Talluri V, Nagendra S, Krishna R (2017) Bioactive Compounds from Marine Sponge Associates: Antibiotics from Bacillus sp. Natural Products Chemistry \& Research 5: 266. doi: 10.4172/2329-6836.1000266.

Sartini S, Suryadi, Zainuddin E (2014) Isolation and screening fungal symbiont in green alga Ulva reticulata as candidate of antibiotic producer. Asian Journal of Microbiology Biotechnology Enviromental Science 16: 475-478.

Thao NP, Hanh TTH, Tu VA, Huong PTM, Van Thanh N, Cuong NX, Nam NH, Do Cong, Thung PVK, Kim YH, Van Minh C (2015) Chemical constituents from the starfish Protoreaster nodosus. Vietnam Journal of Chemistry 53(2e) 33-36.

Thomas TRA, Kavlekar DP, LokaBharathi PA (2010) Marine drugs from sponge-microbe association-A review. Marine Drugs 8: $1417-1468$.

Journal of Experimental Biology and Agricultural Sciences

http://www.jebas.org 